The International Economy, No.15, 2011

\title{
Economic Impacts of Free Trade Agreements (FTAs)
}

\author{
Shujiro, Urata ${ }^{\dagger}$ \\ Waseda University
}

\begin{abstract}
This paper analyzes the impacts of free trade agreements (FTAs) from both quality and quantity aspects. The qualitative analysis of FTAs in terms of trade in goods, trade in services, direct investment and safeguard measures showed higher level of liberalization for FTAs involving developed countries than developing countries. The analysis of the quantitative effects showed a trade expansion effect for many FTAs. The analysis found various obstacles, which include high cost of obtaining a certificate of origin and low FTA preferential tariff margins, for using FTAs. The obstacles have to be removed, in order to increase the use of FTAs, thereby to promote foreign trade.
\end{abstract}

Key words: FTA, East Asia, CGE model, Gravity model

\section{Introduction}

Free Trade Agreements (FTA) have come to dominate global trading systems. ${ }^{1)}$ From the establishment of the General Agreement on Tariffs and Trade (GATT) in 1948 to around 1990, the number of FTAs amounted to approximately 50. A rapid increase was then seen in the 1990s and the increasing trend accelerated after the creation of the World Trade Organization (WTO) in 1995. By the end of September 2010, there were as many as 288 active FTAs. ${ }^{2}$ In fact, Mongolia is said to be the only WTO member that has yet to enter into an FTA.

Compared with other regions, East Asia was slow to develop an interest in FTAs. There has been a strong opinion in East Asia that the region's high level of economic growth has been achieved as a result of opening up to trade and investment from around the world, rather than only to specific countries or regions. As a result, in many countries there has been opposition to FTAs, which remove barriers to trade between specific countries. Indeed, the only major FTA entered into in East Asia before the start of the $21^{\text {st }}$ century was the ASEAN

Received and Accepted 16 August 2011.

$\dagger$ Corresponding Author: Graduate School of Asia-Pacific Studies, Waseda University, Nishi-Waseda 1-21-1, Shinjuku-ku, Tokyo 169-0051, Japan. E-mail: surata@waseda.jp

1) The World Trade Organization (WTO) refers to free trade agreements (FTA) and customs unions collectively as regional trade agreements (RTA). Given that $90 \%$ of RTAs are FTAs and the fact that practically all East Asian RTAs, which are the subjects of this paper, are FTAs, in this paper FTAs and RTAs should be treated as the same term unless special circumstances apply or special comment is made.

2) WTO website, http://rtais.wto.org/UI/publicsummarytable.aspx 
Free Trade Area (AFTA), signed up to by the countries of the Association of Southeast Asian Nations (ASEAN). However, in the $21^{\text {st }}$ century FTAs in a variety of combinations have been entered into between the likes of Japan, Singapore, China and ASEAN. ${ }^{3)}$ In fact, bilateral or minilateral FTAs have been set up between most countries in East Asia. However, an FTA that covers all of the countries of East Asia is still at the conceptual stage and negotiations have yet to be started.

With FTAs rapidly increasing, there has been rising interest in the impact of FTAs on trade and economies from policymakers and researchers. However, little time has passed since the rapid increase in FTAs in East Asia and thus there has yet to be much empirical analysis of FTAs. As multilateral trade liberalization negotiations under the WTO effectively stalled, there is expected to be a further increase in FTAs in the future. With this in mind, I undertook research to study the economic impacts of FTAs with a group of researchers at the Research Institute of Economy, Trade and Industry (RIETI). This article presents major findings from this research.

We used three methods to analyze the effects of FTAs. The first method of analysis was to examine the provisions contained in the text of the FTAs and evaluate FTAs from the perspective of trade and investment liberalization. This analysis is described here as the qualitative analysis of FTAs. When an FTA has a high level of liberalization, strong expansion of trade/investment can be expected. In the qualitative analysis of FTAs we selected the three categories of trade in goods, trade in services, and foreign direct investment (direct investment, hereafter) and carried out a comparative examination against provisions related to these categories contained in the text of the FTAs. The second and third methods are related to the quantitative effects of FTAs, and the difference between them lies in the timing of the analysis. In the second method, an ex-ante analysis is carried out before an FTA comes into effect, whereas in the third method an ex-post analysis is carried out after an FTA has come into effect. In the ex-ante analysis, a computable general equilibrium (CGE) model is used to carry out a simulation and analyze the economic effects of the establishment of the FTA. In the ex-post analysis, analyses of the usage of the FTA and the impact on trade of the FTA using a gravity model are carried out.

The remainder of the paper is organized as follows. Section 2 analyzes the results of the qualitative analysis into FTAs, while section 3 discusses the results of the ex-ante and ex-post analyses of the quantitative effects of FTAs. Section 4 presents some concluding remarks.

\section{Qualitative Analysis of FTAs}

\subsection{Trade in Goods}

Cheong and Cho (2010) analyzed the quality of FTAs by examining provisions related to trade in goods. Specifically, they carried out a comparative examination of the quality of a variety of FTAs regarding country of origin regulations and the handling of liberalization in agricultural products. Before I explain the results of this research, first let me provide a brief explanation of FTAs.

In an FTA, tariffs on trade between signatory countries are abolished but signatory countries apply tariffs independently upon non-signatory countries. ${ }^{4)}$ For the purposes of the

3) See for example Zhang and Shen (2011) for FTA trends in East Asia. 


\section{S. Urata}

explanation, let us use the example of three countries, Japan, Singapore and the United States, and suppose that Japan and Singapore have entered into an FTA. Japan and Singapore are the FTA signatory countries and the United States is the non-signatory country. Let us suppose that prior to entry into the FTA Japan and Singapore applied import tariffs of 10\% and $2 \%$, respectively. Once Japan and Singapore enter into an FTA, tariffs on trade between the two countries are abolished, and Japan and Singapore apply independent tariff rates ( $10 \%$ in the case of Japan and $2 \%$ in the case of Singapore) to imports from the United States as a non-signatory country. Despite FTAs offering a system of preferential treatment in the form of tariff exemptions for products produced in signatory countries, there is the possibility of products produced in a non-signatory country being imported into the country with high tariff rates via the country with low tariff rates. In the above case, a product produced in the United States could be imported into Singapore, which has a low tariff rate, and then imported free of charge from Singapore to Japan. Such cases are referred to as trade deflection and this would render the preferential treatment given to FTA signatory countries meaningless. As a way of avoiding trade deflection, a certificate of origin must be submitted to prove that a product was produced in a signatory country in order for the traded product to make use of the FTA.

Rules of origin need to be satisfied in order to acquire a certificate of origin. In terms of the standards for recognizing country of origin, there is the wholly-produced standard and the substantial transformation standard. The wholly-produced standard requires a product to have been "produced entirely" (for example, for cattle to have been born and reared in a certain country) within the FTA signatory country. This standard is applied mostly to agricultural produce and minerals. ${ }^{5)}$ The substantial transformation standard sets out the details for sufficient "substantial production and processing" as required to provide originating status in the case of a product made using raw materials imported from a third country. The following three criteria are generally adopted in the case of the substantial transformation standard.

Change in Tariff Classification (CTC) is a rule that confers originating status by deeming there to have been substantial change when production or processing is carried out within the FTA signatory country such that there is a difference in tariff classification number between the raw materials imported from a third country and the produced product. Regional Value Content (RVC) is a rule that calculates the value added from work (procurement, production, processing etc.) carried out within the FTA signatory country and confers originating status to a product by deeming there to have been a substantial change when value added passes a given standard value. Specific Process (SP) is a rule that confers originating status to a product by deeming there to have been a substantial change in the case that a specific production or process is carried out within the FTA signatory country. This rule is sometimes applied to chemical products, certain agricultural products and semi-conductors etc.

The above explanations cover the three criteria related to rules of origin, and many FTAs choose which rules to apply by product. In the case of AFTA and the ASEAN-China FTA

4) The trade policy that signatory countries apply the same import tariffs on non-signatory countries while eliminating tariffs on trade between signatory countries is referred to as a customs union. While both FTAs and customs unions are recognized as forms of regional integration under the GATT/WTO, the closer relationship contained in a customs union in comparison to an FTA is regarded as a deeper form of regional integration.

5) Discussions on rules of origin here are mostly adopted from METI (2010). 
there is a simple application of $40 \% \mathrm{RVC}$ for all products. ${ }^{6)}$

Cheong and Cho (2010) used a restrictiveness index to measure the strictness of rules of origin applied in FTAs. For example, in the case of CTC, using broad classifications to define customs classification numbers is more restrictive on imports than using detailed classifications. Moreover, requiring multiple criteria rather than a single criterion to acknowledge country of origin can lead to considerable restrictions on imports. In this way, Cheong and Cho used a restrictiveness index (the higher the number the more restrictive the rules) to evaluate the rules of origin applied to a variety of FTAs. The targeted FTAs and respective results were as follows: North American Free Trade Agreement (NAFTA) (0.67), Japan-Mexico FTA (0.54), European Union (EU) (0.53), Japan-Singapore FTA (0.49), South Korea-Chile FTA (0.47), South Korea-Singapore FTA (0.44), and United StatesSingapore FTA (0.39). Given the small sample it is difficult to observe any trends, but if we take other research results and data into account it would appear that FTAs between developed countries are more restrictive than FTAs which have at least one developing country as signatory. However, the Japan-Mexico FTA is an exception to this rule.

Under GATT/WTO rules (GATT Article XXIV), the liberalization of "substantially all trade" between signatory countries to an FTA is obligatory. ${ }^{7)}$ However, there has been a variety of discussions about the interpretation of "substantially all trade." Many countries deal with products that are difficult to liberalize (sensitive items) in various ways, such as delaying the timing of liberalization or making such products exceptions to liberalization. Developing countries often impose high tariffs on industrial products, whereas in developed countries there are normally low tariffs on industrial products and a high degree of liberalization. On the other hand, developed countries often impose high tariffs on agricultural products and protect agriculture.

Based on these conditions, Cheong and Cho (2010) analyzed the status of trade liberalization of agricultural products in FTAs with signatory countries such as the United States, Australia, Japan, South Korea, Mexico, Chile and Singapore. In the analysis, customs nomenclature was classified into items to be liberalized within the next 10 years, items to be liberalized later than 10 years in the future, and items exempt from liberalization. The results of the analysis can be seen in Table 1. A number of very interesting results can be seen. Firstly, it is clear that there is a low level of liberalization in Japan, the EU, South Korea and Mexico. However, even among these countries, Japan's exclusion of $60 \%$ of items in its FTA with Singapore shows an extremely low level of liberalization. The second observation of interest is the immediate liberalization of $100 \%$ of items by Australia in the FTA between the United States and Australia. Under this FTA, the United States has excluded from liberalization $20 \%$ of agricultural products imported from Australia. Given that the United States has liberalized the import of all agricultural products from Mexico under NAFTA, this shows that the United States is in a disadvantageous position to Australia but an advantageous position to Mexico in terms of the competitiveness of its agricultural products.

Cheong and Cho (2010) carried out a qualitative analysis of FTAs with a focus on import liberalization rules. Specifically, a comparative examination was made of a variety of FTAs regarding rules of origin and handling of agricultural product liberalization in FTAs.

6) Since 2008, AFTA has allowed selection of RVC or CTC rules.

7) These kinds of rules are not applied in FTAs between developing countries. 


\section{S. Urata}

Table 1 Trade Liberalization Ratio for Agricultural Products ( $\%$ in terms of tariff lines)

\begin{tabular}{lcccccc}
\hline FTA & Importers & Exporters & In 10 yrs & After 10 yrs & Exclusion & Total \\
\hline \multirow{2}{*}{ NAFTA } & US & Mexico & 97.0 & 3.0 & 0.0 & 100.0 \\
& Mexico & US & 90.6 & 1.8 & 7.6 & 100.0 \\
\hline \multirow{2}{*}{ Chile-US } & Chile & US & 81.2 & 18.8 & 0.0 & 100.0 \\
& US & Chile & 85.2 & 14.8 & 0.0 & 100.0 \\
\hline \multirow{2}{*}{ US-Australia } & US & Australia & 53.3 & 26.3 & 20.4 & 100.0 \\
& Australia & US & 100.0 & 0.0 & 0.0 & 100.0 \\
\hline \multirow{2}{*}{ EU-Mexico } & EU & Mexico & 59.3 & 0.0 & 40.7 & 100.0 \\
\hline Average & Mexico & EU & 67.9 & 0.0 & 32.1 & 100.0 \\
\hline Japan-Singapore & Japan & Singapore & 39.4 & 0.0 & 60.6 & 100.0 \\
\hline Japan-Mexico & Japan & Mexico & 51.9 & 7.7 & 40.4 & 100.0 \\
\hline Korea-Singapore & Korea & Singapore & 66.0 & 0.0 & 34.0 & 100.0 \\
\hline Korea-Chile & Korea & Chile & 71.5 & 0.8 & 27.7 & 100.0 \\
\hline Average & & & 57.2 & 2.1 & 40.7 & 100.0 \\
\hline
\end{tabular}

Source : Constructed from Cheong and Cho (2010)

Although an FTA represents a decision to liberalize imports and offer favorable treatment to FTA signatory countries, in many cases countries protect their own industries by setting strict rules of origin or restricting the agricultural products that are the target of liberalization. Of the FTAs targeted by Cheong and Cho's research, Japan and South Korea, and particularly Japan, have restricted imports from FTA signatory countries. In FTAs with developing countries, Japan has avoided opening its markets (import liberalization) by offering economic cooperation to the partner country. Currently, FTA negotiations with Australia appear to have reached a deadlock. Opening Japan's markets for agricultural products in line with the wishes of the negotiating partner country seems indispensible to the conclusion of an FTA with a developed country to which economic cooperation cannot be provided.

\subsection{Trade in Services}

There has been an increase in trade in services in recent years. The factors behind this increase include an expansion in the service sector as a proportion of economic activities and a reduction in service transaction costs thanks to liberalization of the service sector, an easing in regulations and technological progress. While there is a variety of different types of trade in services, including finance, transport, healthcare and education, generally speaking service transactions take the form of a service provided directly by a supplier (the producer) to a customer (the consumer). In other words, service transactions require the supplier and the customer to be in the same place at the same time. On the other hand, in the case of goods transactions it is unusual for goods to be supplied directly from the supplier to the customer. If we take the example of an automobile, the vehicle is produced at a factory, transported to a dealer and the customer purchases the vehicle from the dealer. It usually requires several months after production of the vehicle for it to be handed over to the customer. 
Given the above characteristics of trade in services, the World Trade Organization's (WTO) General Agreement on Trade in Services (GATS) focuses on the question of whether there is movement in supplier and/or customer during trade in services, and sets out the following four modes. ${ }^{8}$ Mode 1 (cross-border transactions): a service is provided from one country to another, but there is no movement across borders of either service supplier or customer. An example of this would be receiving legal advice via telephone from a lawyer living overseas. Mode 2 (consumption abroad): the customer moves to the country where the service supplier is located so that the service can be provided to the customer overseas. An example of this would be a tourist making an overseas trip. Mode 3 (commercial presence): a service supplier from one country moves to another country where the customer is located to provide a service via a commercial base. An example of this would be the provision of financial services via an overseas branch. Mode 4 (movement of natural persons): a service supplier (in this case a person) moves from one country to another country where a customer is located so that a natural person can provide a service. An example would be an artist performing overseas.

There are major differences between FTAs in terms of the classification methods, methods of recording liberalization rules (for example, liberalization by sector or liberalization across the whole service sector) and methods for handling direct investment, in reflection of the variety of services traded.

In terms of the classification methods for trade in services, the 155 classifications employed by GATS provide the basic classifications, but independent classifications are often used by each country to record things such as fields excluded from liberalization. In terms of the methods for recording rules on liberalization, there is the positive list approach, which identifies sectors targeted by liberalization, and the negative list approach, which identifies sectors excluded from liberalization. The positive list approach is used by GATS and as a result is known as the GATS method. On the other hand, the negative list approach is employed by NAFTA and is consequently referred to as the NAFTA type. Generally speaking, the negative list approach has a higher level of liberalization than the positive list approach. In terms of liberalization by sector, many FTAs have a larger scope of liberalization than GATS rules, but there are also several cases when the effective level of liberalization is restricted by the application of domestic regulations etc.

Ochiai et al. (2010) carried out a comparative analysis of the level of liberalization of trade in services in 11 FTAs, including NAFTA, the European Free Trade Association (EFTA), United States-Singapore, Japan-Mexico, Chile-South Korea, South KoreaSingapore, Australia-United States, Australia-New Zealand (CER), Mexico-EU, AFTA, and Japan-Singapore. In the analysis, the level of liberalization was examined after first creating indices such as the scope of liberalization of trade in services, most-favored nation treatment, national treatment, national regulations etc. 138 services sectors were targeted, with scores allocated for the four modes.

The results of the analysis can be seen in Table 2. In terms of the overall figures, CER and EFTA have the highest levels of liberalization, and the Chile-South Korea FTA and NAFTA have the lowest levels of liberalization. The Japan-Mexico FTA and JapanSingapore FTA ranked $4^{\text {th }}$ and $7^{\text {th }}$ respectively. With a small sample of only 11 FTAs it

8) See METI (2010). 
S. Urata

Table 2 Comparison of Liberalization of Trade in Services among FTAs

\begin{tabular}{|c|c|c|c|c|c|c|c|}
\hline Modes 1 and 2 & & Mode 3 & & Mode 4 & & Total & \\
\hline CER & 9.085 & CER & 7.950 & EFTA & 11.231 & CER & 9.369 \\
\hline Australia-US & 8.601 & EU-Mexico & 7.872 & CER & 11.072 & EFTA & 9.078 \\
\hline EFTA & 8.296 & Japan-Mexio & 7.716 & Korea-Singapore & 9.904 & EU-Mexico & 8.277 \\
\hline AFTA & 8.048 & EFTA & 7.706 & EU-Mexico & 9.514 & Japan-Mexico & 7.859 \\
\hline Japan-Singapore & 7.924 & Australia-US & 7.379 & Japan-Mexico & 9.492 & Singapore-US & 7.817 \\
\hline EU-Mexico & 7.445 & Singapore-US & 7.241 & Singpoare-US & 9.251 & Australia-US & 7.767 \\
\hline NAFTA & 7.234 & NAFTA & 6.871 & Chile-Korea & 9.131 & Japan-Singapore & 7.760 \\
\hline Singapore-US & 6.958 & Chile-Korea & 6.835 & AFTA & 9.036 & Korea-Singapore & 7.686 \\
\hline Korea-Singapore & 6.645 & Korea-Singapore & 6.509 & Japan-Singapore & 8.886 & AFTA & 7.556 \\
\hline Japan-Mexico & 6.370 & Japan-Singapore & 6.469 & NAFTA & 8.338 & NAFTA & 7.481 \\
\hline Chile-Korea & 5.471 & AFTA & 5.583 & Australia-US & 7.320 & Chile-Korea & 7.146 \\
\hline
\end{tabular}

Source: Constructed from Ochiai et al. (2010)

is difficult to make a hard-and-fast judgment, but a trend can be seen whereby FTAs including developing countries such as Chile, South Korea, Mexico and the countries of ASEAN have a lower level of liberalization. In terms of trade in services, developing countries tend to lose out to developed countries in competitive terms and the observed results are in line with the expected relationship.

In terms of the level of liberalization of trade in services by mode, CER has a high level of liberalization across all modes, ranking $1^{\text {st }}$ in Mode 1 , Mode 2 and Mode 3 , and $2^{\text {nd }}$ in Mode 4 . The $1^{\text {st }}$ ranking FTA in Mode 4 is EFTA. EFTA shows a high level of liberalization in all modes, ranking $3^{\text {rd }}$ in Mode 1 and Mode 2, and $4^{\text {th }}$ in Mode 3. The Mexico-EU FTA, which ranks $3^{\text {rd }}$ overall, has a middle ranking of $6^{\text {th }}$ in Mode 1 and Mode 2 , but ranks $2^{\text {nd }}$ in Mode 3 and $4^{\text {th }}$ in Mode 4, showing a relatively high ranking across all modes. FTAs other than CER, EFTA and the Mexico-EU FTA vary greatly by mode. For example, the Australia-United States FTA ranks highly at $2^{\text {nd }}$ in Mode 1 and Mode 2, but also ranks $5^{\text {th }}$ in Mode 3 and has the lowest rank at $11^{\text {th }}$ in Mode 4. The Japan-Singapore FTA ranks $5^{\text {th }}$ in Mode 1 and Mode 2, $10^{\text {th }}$ in Mode 3 and $9^{\text {th }}$ in Mode 4 and the Japan-Mexico FTA ranks $10^{\text {th }}$ in Mode 1 and Mode 2, $3^{\text {rd }}$ in Mode 3 and $5^{\text {th }}$ in Mode 4, showing great variation between modes.

Ochiai et al. (2010) carried out the same analysis for 70 other FTAs in addition to the above 11, and compiled analytical results by FTA signatory country (FTAs between developed countries, between developing countries and between developed and developing countries). The results show that FTAs have the lowest level of liberalization when entered into between developing countries. It also became clear that the highest level of liberalization occurs when FTAs are entered into between developed countries and developing countries, and that there is a middle level of liberalization in the case of FTAs between developed countries. 


\subsection{Direct Investment}

Since the 1980s, direct investment has played an increasingly important role in international economic activities. This can be confirmed by the rapid expansion in global direct investment in comparison to global GDP or trade. In fact, in the 24-year period from 1980 to 2004, while global GDP expanded 4 times and global trade expanded by a factor of 5, global direct investment grew by an astonishing 11 times. Direct investment has contributed to economic growth in the recipient countries through a variety of channels. Specifically, direct investment not only increases production and employment in the recipient country, it also transfers technology and management knowhow, which make an important contribution to economic development and growth. What's more, direct investment also allows the recipient country to participate in the sales and procurement networks of multinational corporations making the direct investment. Many countries in East Asia, including China, have achieved a high level of economic growth after successfully receiving large volumes of direct investment.

Direct investment is often seen as having negative impacts on the investing country, such as the hollowing out of industry. However, in cases when industries that have lost competitiveness in the investing country are transferred overseas via direct investment, there is a good possibility of the labor and other resources that remain in the investing country being used in competitive industries, helping to invigorate the economy of the investing country. In fact, in Japan and many other countries this has contributed to economic growth by moving resources from non-productive fields to productive fields. This process is accelerated through the use of direct investment. Moreover, multinational corporations carrying out direct investment are able to use direct investment to implement optimum placement of a variety of functions, allowing them to improve overall efficiency. One strategy would be a company concentrating the construction of corporate strategy or research and development at its headquarters while carrying out product manufacture at an overseas subsidiary.

A number of factors can be seen behind the rapid increase in direct investment in East Asia and throughout the world. The most important factor is the liberalization of direct investment policy. Specifically, liberalization has been promoted in a variety of ways, including opening up fields in which direct investment was previously restricted or relaxing the equity participation ratio by multinational companies. In fact, in order to obtain the benefits brought about by direct investment, several countries even employ preferential treatment such as exemption from corporate income tax.

The liberalization of direct investment policy has progressed, but overseas investors such as multinational corporations claim considerable scope for further liberalization remains. In reflection of this view, during multilateral trade negotiations held under the World Trade Organization (WTO), developed countries argued for the formulation of international rules on direct investment and promotion of the liberalization of direct investment. However, the creation of rules and further liberalization at the WTO came to nothing after strong opposition from developing countries fearful of the control of competitive multinational companies from developed countries.

Under these circumstances, multinational companies, faced with restrictions and regulations on direct investment, demanded the liberalization of direct investment policy through the conclusion of FTAs. ${ }^{9}$ ) Some FTAs do not include rules on direct investment, but most of

9) Restrictions on direct investments are also handled by bilateral investment treaties (BITs). Historically speaking, BITs came before FTAs. 


\section{S. Urata}

the FTAs set up by developed countries such as Japan do cover direct investment. These rules include those on market access (right to establish companies), national treatment and performance requirements such as local content and employment requirements.

Urata and Sasuya (2010) analyzed levels of liberalization by examining the content of rules on direct investment in FTAs, with a focus on FTAs involving countries from East Asia. ${ }^{10)}$ Specifically, the analysis targeted the seven FTAs between Japan-Singapore, JapanMexico, NAFTA, Australia-United States, United States-Singapore, South Korea-Singapore and South Korea-Chile. The analysis targeted the following six categories of rules on direct investment: (1) market access/ right of establishment; (2) national treatment; (3) approval and screening procedure; (4) composition of boards of directors; (5) issue of visas to foreign investors; (6) performance requirements. Liberalization standards were set for each item, and the level of FTA liberalization was evaluated based on the information recorded in FTA text. For example, in the case of market access and right of establishment regulation, " 0 " was given in the case that no investment at all is permitted and " 1 " in the case that the market was completely open. In the case that the level of liberalization fell somewhere in between, the ratio of possible investment was divided into 5 stages and points were awarded for each stage. The analysis divided industry into 158 sectors, with scores awarded to each industry and overall scores were computed by means of a simple average of the scores in each sector.

The results of the analysis can be seen in Table 3 . While the maximum score within each category was 1 as described above, weighting was given to each item in line with the importance of the category. Consequently, the maximum scores shown in Table 3 are 0.4 in the case of investment restrictions and market access, 0.2 in the case of national treatment, and 0.1 in the other categories. Given that FTAs can have two or three signatory countries, FTAs were evaluated by scoring each country and then calculating a simple average for the FTA score. According to the results of the analysis, the FTA with the highest level of liberalization is the United States-Australia FTA, followed by the United States-Singapore FTA. Meanwhile, the FTA with the lowest level of liberalization is the Japan-Mexico FTA, and the FTA with the second lowest level of liberalization is the South Korea-Chile FTA. In terms of the other FTAs, the Japan-Singapore FTA ranked $3^{\text {rd }}$, the South Korea-Singapore FTA ranked $4^{\text {th }}$ and NAFTA ranked $5^{\text {th }}$.

It goes without saying that, because FTAs have multiple signatory countries, evaluating each FTA does not reveal the investment policy of the participating countries. Calculations of the level of liberalization in investment policy by country based on the scores in Table 3 were as follows: (1) United States (0.881); (2) Singapore (0.778); (3) Australia (0.770); (4) Japan (0.762); (5) South Korea (0.699); (6) Chile (0.673); (7) Mexico (0.627); (8) Canada (0.620). While there is a higher level of liberalization in direct investment policy in developed countries than in developing countries, Canada is an exception among developed countries, with a particularly low level of liberalization. In the case of Canada, there are several sectors closed to foreign capital and even when a sector is open to foreign capital strict investment restrictions are imposed. Moreover, restrictions have been put in place ensuring that a majority of board members have Canadian nationality. While Japan has a relatively low level of liberalization in comparison to the United States, it holds up well against the

10) The analytical methods used in this article are based on the method developed by Golub (2003), with certain changes. 
Economic Impacts of Free Trade Agreements (FTAs)

Table 3 Degrees of Restriction of Selected FTAs by Types of Restriction

\begin{tabular}{|c|c|c|c|c|c|c|c|c|}
\hline FTA Members & $\begin{array}{l}\text { Limitation } \\
\text { of } \\
\text { foreign } \\
\text { ownership/ } \\
\text { Market } \\
\text { access }\end{array}$ & $\begin{array}{l}\text { National } \\
\text { treatment }\end{array}$ & $\begin{array}{c}\text { Screening } \\
\text { and } \\
\text { approval }\end{array}$ & $\begin{array}{l}\text { Board of } \\
\text { directors }\end{array}$ & $\begin{array}{l}\text { Movement } \\
\text { of investors }\end{array}$ & $\begin{array}{l}\text { Performance } \\
\text { requirement }\end{array}$ & Total & Ranking \\
\hline Weight & 0.4 & 0.2 & 0.1 & 0.1 & 0.1 & 0.1 & 1 & \\
\hline Australia-US & & & & & & & 0.838 & 1 \\
\hline Australia & 0.273 & 0.164 & 0.047 & 0.089 & 0.100 & 0.097 & 0.770 & \\
\hline US & 0.340 & 0.174 & 0.098 & 0.097 & 0.100 & 0.096 & 0.905 & \\
\hline Singapore-US & & & & & & & 0.825 & 2 \\
\hline Singapore & 0.278 & 0.157 & 0.096 & 0.039 & 0.100 & 0.093 & 0.763 & \\
\hline US & 0.326 & 0.172 & 0.098 & 0.096 & 0.100 & 0.096 & 0.888 & \\
\hline Japan-Singapore & & & & & & & 0.767 & 3 \\
\hline Japan & 0.276 & 0.157 & 0.086 & 0.088 & 0.048 & 0.095 & 0.750 & \\
\hline Singapore & 0.343 & 0.158 & 0.089 & 0.045 & 0.050 & 0.098 & 0.784 & \\
\hline Korea-Singapore & & & & & & & 0.741 & 4 \\
\hline Korea & 0.259 & 0.156 & 0.082 & 0.083 & 0.075 & 0.038 & 0.693 & \\
\hline Singapore & 0.310 & 0.173 & 0.095 & 0.046 & 0.075 & 0.088 & 0.788 & \\
\hline NAFTA & & & & & & & 0.710 & 5 \\
\hline Canada & 0.280 & 0.158 & 0.009 & 0.025 & 0.100 & 0.049 & 0.621 & \\
\hline Mexico & 0.222 & 0.135 & 0.023 & 0.089 & 0.095 & 0.089 & 0.654 & \\
\hline US & 0.292 & 0.180 & 0.092 & 0.094 & 0.100 & 0.096 & 0.855 & \\
\hline Chile-Korea & & & & & & & 0.689 & 6 \\
\hline Chile & 0.272 & 0.142 & 0.095 & 0.069 & 0.050 & 0.045 & 0.673 & \\
\hline Korea & 0.271 & 0.146 & 0.063 & 0.082 & 0.050 & 0.091 & 0.704 & \\
\hline Japan-Mexico & & & & & & & 0.687 & 7 \\
\hline Japan & 0.305 & 0.162 & 0.084 & 0.084 & 0.048 & 0.090 & 0.773 & \\
\hline Mexico & 0.234 & 0.142 & 0.024 & 0.065 & 0.048 & 0.088 & 0.601 & \\
\hline
\end{tabular}

Source: Reproduced from Urata and Sasuya (2010)

likes of Singapore and Australia.

While the most common methods for restricting direct investment are related to market access and equity participation ratios, in Canada, Australia and Mexico strict approval and screening are employed to control investment. In Japan, only short stays in the country by foreign investors are permitted and the system is restrictive to investment. By sector, primary sector and tertiary sector are restricted, and manufacturing is considerably open to 
investment. Sectors with particularly strict controls in primary sector include agriculture and mining and in tertiary sector transportation services, telecommunications services and financial services.

In this section, I have analyzed the level of liberalization of direct investment with a focus on FTAs that incorporate rules on direct investment. The analysis is restricted to 7 FTAs involving East Asian countries, and I believe it would be possible to identify more general trends by expanding the scope of the analysis. Moreover, by carrying out similar research in the future it will be possible to observe chronological changes in rules related to direct investment. These are the research challenges that remain for the future.

\section{Impact Analysis}

\subsection{Ex-Ante Analysis: Simulation Analysis using CGE Models}

Analyzing the effect of an existing FTA requires time after the FTA comes into effect to collect the necessary data. For this reason, ex ante analyses, which use CGE models to estimate the effects of FTAs, are often used in effects analyses. These kinds of ex ante analyses can be used not only for real FTAs, including those with only a short time lapse after coming into effect, but can also be used for potential FTAs that have yet to be entered into, making them useful in examining whether or not entry into an FTA is actually necessary and the kinds of FTA it is important to construct.

For example, Ando (2009) carried out a simulation analysis of the economic effects of East Asian FTAs with a focus on trade liberalization, facilitation and technical assistance, and examined the desirable FTA membership. ${ }^{11)}$ Regarding trade liberalization, in light of the difficulties in making substantial and rapid progress in the liberalization of the agricultural sector, on which WTO negotiations have come to a standstill, a simulation was carried out to reflect the arguments on liberalization of the agricultural sector by examining the cases of partial removal of trade obstacles in the agricultural sector and no removal whatsoever, in addition to the case of abolishing trade obstacles in all industry. Trade facilitation means improvements to the efficiency of imports through a variety of facilitation measures, such as simplifying customs procedures at time of import, introducing mutual verification systems and expanding applicable items. Moreover, technical assistance provided to developing countries was incorporated into the models in the form of improvements made to productivity in developing countries as a result of technical assistance.

The East Asian FTAs (including both existing and hypothetical) targeted by the analysis were ASEAN, ASEAN+3, ASEAN+6, and Asia-Pacific Economic Cooperation (APEC) FTAs, as well as multiple ASEAN+1 FTAs (referred to below as "(ASEAN + 1 FTA) $\times 3$ " and "(ASEAN+1 FTA $) \times 6$ ") between the countries of ASEAN+3 and ASEAN+6. ${ }^{12)}$ Ando estimated the effect of these FTAs based on the following five scenarios: (1) trade liberalization with the exception of the agricultural sector (Sim1); (2) partial (half) removal of trade

11) Ando (2009) used the sixth version of the GTAP database, which is based on the 2001 global economy to collect and analyze data on 87 countries and regions and 57 industries, aggregated into 18 countries and regions and 16 industries.

12) ASEAN+3 refers to ASEAN, Japan, China and South Korea. ASEAN+6 refers to ASEAN+3, plus Australia, New Zealand and India. 
barriers in the agricultural sector and trade liberalization of other industries (Sim2); (3) trade liberalization of all industries (Sim3); (4) trade liberalization and facilitation of all industries (Sim4); (5) trade liberalization and facilitation of all industries plus technological support to developing countries. When examining the effect of (ASEAN +1 FTA $) \times 3$ and (ASEAN +1 FTA) $\times 6$, adjustments were made for the facilitation element of Sim 4 in order to take into account the inefficiencies caused by the lack of common rules of origin.

Some extremely interesting observations can be made as a result of the above analysis. ${ }^{13)}$ First, regarding the liberalization of trade, there is a need to promote trade liberalization, including the agricultural sector. Comparing the analytical results of the three scenarios with different handling of the agricultural sector (Sim1 - Sim3), a greater economic impact can be seen in terms of GDP, economic welfare and trade for ASEAN, ASEAN+3, ASEAN+6 and APEC as a whole in the case of partial trade liberalization of the agricultural sector compared to no liberalization, and a greater impact in the case of the total removal of trade barriers including the agricultural sector than in the case of only partial removal of trade barriers in the agricultural sector. Looking at the results by country, the same trend can be seen for almost all countries. In the case of China and India in particular, a major deterioration can be seen in the case that liberalization does not include the agricultural sector, and the reasons for this are the deterioration in the increased inefficiencies of resource allocation and deteriorated terms of trade that would result from failing to target agriculture when liberalizing trade. The importance of liberalization of the agricultural sector is also clear from Abe (2010), who analyzed the effects of multiple combinations of Japan's bilateral FTAs. It is necessary for the regional economy, including Japan, to promote trade liberalization, including the agricultural sector.

Second, trade facilitation and technical assistance are also important in addition to trade liberalization. As suggested by the Sim3 results shown in Table 4, while trade liberalization certainly brings about certain economic effects, such as the abolition or reduction of tariffs, on its own this cannot be expected to have a major economic effect. The important thing is the utilization of policy measures other than trade liberalization. As can be guessed from the fact that Sim4 (trade liberalization and facilitation) has a greater economic impact than Sim3 (trade liberalization), in East Asia it is important to promote a variety of facilitation measures such as simplifying import procedures, in addition to trade liberalization. Improvements in efficiency related to imports means a reduction in service link costs linking production blocs with diversified locations across national borders. If a variety of facilitation measures can be implemented to reduce service link costs across national borders, it will become possible to develop even further the international production and distribution networks currently in place across East Asia.

The far bigger impact of Sim5 (trade liberalization, trade facilitation and technological support) in comparison to Sim4 (trade liberalization and trade facilitation) suggests a large impact from technical assistance. In developed countries, liberalization of trade has already progressed to a high level, with the exception of certain industries. Moreover, in the developing countries of East Asia the actual tariff burden is likely to be lower than the tariff rate because of the implementation of tariff exemptions and drawbacks related to the import

13) Only the results for Simulation 3-5 are shown in this article (Table 4). See Ando (2009) for detailed discussions on the results from all simulations. 


\section{S. Urata}

Table 4 Economic Impacts of FTAs in East Asia: Percentage growth in terms of GDP

\begin{tabular}{|c|c|c|c|c|c|c|c|c|c|c|c|c|c|}
\hline & \multirow{2}{*}{$\frac{\text { ASEAN }}{\operatorname{Sim} 3}$} & \multicolumn{2}{|c|}{$(\mathrm{ASEAN}+1) \times 3$} & \multicolumn{3}{|c|}{ ASEAN+3 } & \multicolumn{2}{|c|}{$(\mathrm{ASEAN}+1) \times 6$} & \multicolumn{3}{|c|}{ ASEAN+6 } & \multicolumn{2}{|c|}{ APEC } \\
\hline & & $\operatorname{Sim} 3$ & $\operatorname{Sim} 4$ & $\operatorname{Sim} 3$ & Sim4 & $\operatorname{Sim} 5$ & $\operatorname{Sim} 3$ & Sim4 & Sim3 & $\operatorname{Sim} 4$ & $\operatorname{Sim} 5$ & Sim 3 & Sim4 \\
\hline Japan & 0.00 & 0.00 & 0.08 & 0.01 & 0.44 & 0.44 & -0.01 & 0.07 & 0.05 & 0.54 & 0.54 & 0.11 & 0.91 \\
\hline China & 0.00 & 0.01 & 0.19 & 0.13 & 1.66 & 4.73 & 0.01 & 0.19 & 0.15 & 1.77 & 4.84 & 0.99 & 3.67 \\
\hline Korea & -0.01 & -0.05 & 0.19 & 1.13 & 3.56 & 3.55 & -0.04 & 0.20 & 1.15 & 3.72 & 3.71 & 1.50 & 5.04 \\
\hline Indonesia & 0.02 & 0.07 & 0.90 & 0.07 & 1.74 & 3.94 & 0.07 & 1.01 & 0.07 & 1.94 & 4.14 & 0.10 & 2.47 \\
\hline Malaysia & 0.05 & 0.42 & 3.11 & 0.39 & 5.83 & 8.62 & 0.51 & 3.34 & 0.50 & 6.21 & 9.00 & 0.76 & 8.06 \\
\hline Philippines & 0.17 & 0.18 & 2.06 & 0.21 & 3.94 & 6.27 & 0.20 & 2.18 & 0.25 & 4.18 & 6.52 & 0.39 & 6.06 \\
\hline Singapore & 0.07 & 0.09 & 2.18 & 0.06 & 4.22 & 4.24 & 0.10 & 2.30 & 0.05 & 4.40 & 4.42 & 0.02 & 6.05 \\
\hline Thailand & 0.09 & 0.73 & 2.62 & 0.68 & 4.48 & 7.02 & 0.80 & 2.82 & 0.74 & 4.78 & 7.32 & 0.77 & 5.62 \\
\hline Vietnam & 0.54 & 2.29 & 4.81 & 2.21 & 7.08 & 9.67 & 2.33 & 4.97 & 2.25 & 7.33 & 9.92 & 3.53 & 10.42 \\
\hline Others* & 0.01 & 0.09 & 0.49 & 0.09 & 0.88 & 2.91 & 0.11 & 0.52 & 0.10 & 0.92 & 2.95 & 0.12 & 1.07 \\
\hline Australia & 0.00 & -0.02 & -0.03 & -0.03 & -0.09 & -0.09 & 0.01 & 0.16 & 0.16 & 1.35 & 1.35 & 0.15 & 1.81 \\
\hline New Zealand & -0.01 & -0.02 & -0.02 & -0.02 & -0.06 & -0.06 & 0.00 & 0.14 & 0.10 & 1.87 & 1.87 & 0.12 & 2.61 \\
\hline India & -0.01 & -0.03 & -0.06 & -0.04 & -0.10 & -0.10 & 0.31 & 0.51 & 0.41 & 1.30 & 3.45 & -0.10 & -0.26 \\
\hline ASEAN & 0.09 & 0.38 & 2.00 & 0.36 & 3.60 & 5.67 & 0.41 & 2.14 & 0.39 & 3.83 & 5.89 & 0.53 & 5.01 \\
\hline $\mathrm{ASEAN}+3$ & 0.01 & 0.03 & 0.29 & 0.14 & 1.18 & 1.93 & 0.04 & 0.30 & 0.17 & 1.30 & 2.05 & 0.40 & 2.08 \\
\hline $\mathrm{ASEAN}+6$ & 0.01 & 0.03 & 0.25 & 0.12 & 1.02 & 1.68 & 0.05 & 0.31 & 0.19 & 1.30 & 2.11 & 0.36 & 1.92 \\
\hline APEC & 0.00 & 0.01 & 0.09 & 0.04 & 0.38 & 0.63 & 0.01 & 0.10 & 0.06 & 0.45 & 0.71 & 0.15 & 1.50 \\
\hline World & 0.00 & 0.00 & 0.05 & 0.02 & 0.22 & 0.38 & 0.01 & 0.07 & 0.04 & 0.28 & 0.47 & 0.08 & 0.87 \\
\hline
\end{tabular}

Note: “*” indicates other Southeast Asian countries. The countries with shade are FTA members.

Source: Constructed from Ando (2009)

of components and intermediate goods used in export goods production, particularly in the machinery industry, including the electric and electronic industries. The formulation of FTAs with more comprehensive content, such as trade facilitation and technical assistance, could be expected to have a greater impact than trade liberalization alone.

Third, the more countries that participate in an FTA the greater the economic impact there is. Looking at the analytical results, there is a trend towards greater impact on the GDP and economic welfare of the countries within the region the larger the number of participating countries, such as ASEAN, ASEAN+3, ASEAN+6 and APEC. ${ }^{14)}$ For example, if we compare the results for ASEAN+3 and ASEAN+6, not only does ASEAN+6 bring about an additional economic impact for Australia, New Zealand and India, which are not included in ASEAN+3, a greater economic impact can also be seen in the countries and regional economy of ASEAN+3.

14) The static and dynamic simulation results in Abe (2010) also suggest that entering into a large regional FTA including Japan or an FTA with a larger number of participating countries would have a bigger impact on all members including Japan than the formulation of multiple bilateral FTAs with Japan. Usually, the main difference between static and dynamic models is the international movement of capital and resulting capital accumulation (investment process). 
Moreover, if we focus on (ASEAN +1$) \times 3$ and $($ ASEAN +1$) \times 6$ and compare these with an ASEAN+3 FTA and an ASEAN+6 FTA, in the case that measures are restricted to trade liberalization there is a small but comparatively greater impact in certain ASEAN nations from the multiple ASEAN+1 FTAs. This may be due to the result of the trade diversion from ASEAN countries to China that would come about as a result of the liberalization of trade between China, Japan and South Korea because of the high proportion of Japan-China-South Korea trade (equivalent to a third of trade in the case of ASEAN+6) and high tariffs on this trade. However, because different definitions of rules of origin exist for each FTA in the case of $($ ASEAN +1$) \times 3$ and $($ ASEAN +1$) \times 6$, there are no common rules of origin, unlike an ASEAN+3 FTA or an ASEAN+6 FTA. In Sim4, which analyzes the effect of trade liberalization and facilitation in consideration of this inconsistency, we obtain a result showing that an ASEAN+3 FTA or ASEAN+6 FTA would be better for all ASEAN countries. Furthermore, if it were also possible to include technical assistance within an ASEAN+6 FTA, the incentives for ASEAN countries to form an ASEAN +6 FTA would also be considered likely to grow. Accordingly, it is likely that a greater economic impact could be expected from the more numerous signatory countries and regions of an ASEAN+6 FTA than an ASEAN+3 FTA, and that the extent to which more comprehensive policy measures could be incorporated in addition to trade liberalization would have a major impact on the incentives for the ASEAN +6 countries to formulate an FTA.

Lastly, in this section, I want to argue for the importance of building mechanisms that create simple and easy-to-use FTAs. In the simulations, the immediate abolition of trade barriers has been assumed because of the nature of the analysis. However, in the case of real FTAs there are often items for which tariffs are reduced and abolished gradually over a period of many years. Cases also arise when major reductions are made in general MFN tariffs at the time an FTA is entered into, whereby the preferential tariffs contained in the schedule set by the FTA are actually higher than the MFN tariffs and not using the preferential tariff leads to a lower tariff rate. What's more, in the case of Japanese FTAs there is a trend towards complicated MFN tariff systems remaining unchanged within the FTA, particularly in the agricultural sector. There is no point in entering into an FTA if it cannot be used. It is preferable to make the tariff system within FTAs as simple as possible, including the immediate abolition of tariffs. What's more, in the case of trade liberalization, while it goes without saying that multilateral liberalization is preferable there is a need to recognize that, although FTAs discriminate in a way that is incompatible with the WTO's philosophy of non-discrimination, the advantages that FTAs have over the WTO system (including greater variety of targeted sectors, more flexibility and speed) far outweigh this negative impact. Considerable costs to other sectors can be incurred in the event that an FTA is not entered into because of an ongoing reluctant stance towards an FTA in an attempt to avoid the liberalization of certain sectors. There is a need to make active and effective use of FTAs to avoid missing out on the current wave.

\subsection{Ex-Post Analysis}

\subsubsection{Analysis of Use of FTAs}

When using an FTA it is essential to acquire a certificate of origin. Accordingly, we can examine the level of use of FTAs by obtaining information on the acquisition and use of certificates of origin. Before launching an analysis of FTA use, let us recall briefly the proce- 


\section{S. Urata}

dures related to the issue of a certificate of origin.

The certificate of origin system for FTAs throughout the world can be divided into two main categories: the third party certification system and the self-certification system. ${ }^{15)}$ In the third party certification system, certification is issued to the exporter by the authorities in the exporting country or by an institution designated by the same authorities. This system is used for all Japanese FTAs with the exception of Switzerland. In the case of Japan, certification is issued by the Japan Chamber of Commerce and Industry. In the self-certification system, the certification is essentially created by the exporter or the importer. Japan uses this system in the case of its FTA with Switzerland, and certification is created by parties approved of by the authorities. When issuing a certificate of origin, it is necessary to collect a variety of information, including the raw materials used in the production of a product. What's more, there is a need to pay a fee for the issue of a certificate of origin. The issuing fee under Japan's third party certification system is 2,000 yen per case.

Table 5 shows the level of use of FTAs in the case of Japan (exports), South Korea (exports and imports), Australia (imports) and Thailand (exports). ${ }^{16)}$ The level of use is calculated using two methods based on information concerning the issue of and use of certificates of origin, as described above. The first method involves using customs clearance statistics and the second method uses the results of questionnaire surveys of companies. The level of FTA use in South Korea, Australia and Thailand was obtained from customs clearance statistics, whereas the level of FTA use in Japan was estimated using a corporate questionnaire survey. It goes without saying that analytical results that make use of customs clearance statistics make a more accurate depiction of the real situation. However, in the case of Japan a questionnaire survey was used because of difficult access to customs clearance statistics.

Regarding the level of FTA use in Japanese exports, a joint questionnaire survey was carried out in cooperation with RIETI and the Japan Chamber of Commerce and Industry, which issues certificates of origin. The questionnaire was sent to 10,953 member companies of the Japan Chamber of Commerce and Industry in February 2008, and responses were received from 1,688 companies (15.4\%). Japan's FTAs with Mexico, Malaysia and Chile were selected from among its FTAs as targets for the survey, as a relatively long time period has elapsed since these FTAs came into effect. Questions were asked regarding issues such as the level of use and problems with use. When calculating the level of use, the ratio of companies using the FTA out of the total number of companies making exports to the country in question was sought. Of the FTAs targeted by the survey, the FTA with the highest level of use was the FTA with Mexico. Of all companies making exports to Mexico, 32.9\% made use of the FTA. The level of use of the FTAs with Chile and Malaysia were $23.7 \%$ and $12.2 \%$ respectively. Although this cannot be seen in Table 5, by industry the highest level of FTA use was seen in transportation machinery and steel products.

An investigation of the level of FTA use in exports was carried out for Thailand and South Korea. The results showed that in the case of Thailand the level of FTA use was 40$60 \%$ for exports to ASEAN countries with the exception of exports to Malaysia. It was clear

15) See METI (2010).

16) Analyses have been published on Japan by Takahashi and Urata (2010), on South Korea by Cheong et al. (2010), on Australia by Pomfret et al. (2010) and on Thailand by Kohpaiboon (2010). 
Economic Impacts of Free Trade Agreements (FTAs)

Table 5 Utilization Ratios of FTAs (\%)

\begin{tabular}{|c|c|c|c|c|c|c|}
\hline Exports & Japan & & Korea & & Thailand & \\
\hline \multirow[t]{6}{*}{ FTA partners } & Mexico & 32.9 & Chile & 96.9 & Indonesia & 61.5 \\
\hline & Malaysia & 12.2 & ASEAN & 2.6 & Malaysia & 25.2 \\
\hline & Chile & 23.7 & & & Philippines & 46.9 \\
\hline & & & & & Vietnam & 46.6 \\
\hline & & & & & Australia & 62.5 \\
\hline & & & & & Japan & 22.7 \\
\hline Imports & Korea & & Australia & & \multicolumn{2}{|c|}{ Adjusted for zero tariffs } \\
\hline \multirow[t]{6}{*}{ FTA partners } & Chile & 90.5 & New Zealand & 50.5 & \multicolumn{2}{|c|}{$95.19-97.60$} \\
\hline & Singapore & 29.8 & South Pacific & 3.2 & \multicolumn{2}{|c|}{$99.32-99.35$} \\
\hline & EFTA & 42.5 & Singapore & 2.9 & \multicolumn{2}{|c|}{$90.99-91.44$} \\
\hline & ASEAN & 43.3 & Thailand & 42.0 & \multicolumn{2}{|c|}{$75.97-78.36$} \\
\hline & & & US & 23.2 & \multicolumn{2}{|c|}{$69.42-82.51$} \\
\hline & & & Chile & 6.5 & \multicolumn{2}{|c|}{$96.05-96.33$} \\
\hline
\end{tabular}

Notes: Data for Japan come from the survey while those for other countries are computed from customs clearance data.

Sources: Takahashi and Urata (2010), Cheong et al. (2010), Pomfret et al. (2010), and Kohpaiboon (2010)

that FTA use increased with the passage of time, which was also the case with FTA use in South Korea. An extremely high level of FTA use in South Korean exports was recognized in the case of its FTA with Chile at 97\%. However, in exports to ASEAN an extremely lower figure was seen, at $2.6 \%$.

In the case of South Korean imports, the study examined FTAs with Chile, Singapore, EFTA and ASEAN. Its FTA with Chile has an extremely high level of use, at $90.5 \%$. The level of use of the FTAs with EFTA and ASEAN was above $40 \%$, but in the case of the FTA with Singapore use was less than $30 \%$. The South Korean study shows a trend towards a rise in FTA use with the passage of time after an FTA has come into effect. For example, usage of the FTA with Chile rose from $77.7 \%$ in the first year to $93.8 \%$ in the second year.

In the case of Australia's FTAs, there are major differences by country in terms of levels of FTA use for imports. While the FTAs with New Zealand and Thailand had high levels of use at between 40-50\%, FTAs with the South Pacific, Singapore and Chile had extremely low levels of use below $10 \%$. One of the reasons for low use of FTAs is the large numbers of imports with zero import tariffs, removing the need to make use of FTAs. Because it is possible to acquire detailed information on Australian imports, the level of FTA use on imported goods excluding zero tariff imports was computed. The result showed a major increase in levels of FTA use to between $80-90 \%$.

A statistical analysis was carried out on Japan and Thailand regarding the factors that determine levels of FTA use. In the analysis of Japan, information related to the usage of FTAs for exports acquired through the corporate questionnaire survey was used, whereas in the analysis of Thailand customs clearance data on exports was combined with data acquired from domestic sources, such as input-output tables. 


\section{S. Urata}

The analysis of Japan shows a positive correlation between FTA use and the size of the company, as expected. The same relationship was also shown by the questionnaire survey in South Korea. These empirical results suggest that the benefits of using FTAs are greater for large companies than small and medium-sized companies. Specifically, this suggests that for small and medium-sized companies the high burden of expenses related to acquiring the certificates of origin for use of FTAs and small transaction volumes mean there is little advantage to be gained from using FTAs. However, for large companies, given the large transaction volumes there is a major advantage to acquiring a single certificate of origin and large companies consequently make use of FTAs because of the small expense burden in comparison to this benefit.

The impact of rules of origin on FTA use is also shown in the analysis on Thailand. Specifically, results showed a higher level of FTA use for products using a large volume of domestically-produced raw materials in production, showing the need to satisfy rules of origin in order to make use of FTAs.

The research on Japan and Thailand shows that the larger the difference between FTA preferential tariff rates (preferential margin), which is the difference between the most favored nation (MFN) tariff rate and the FTA tariff rate, the higher the level of FTA use. These observations are not based on a statistical analysis, but they are compatible with the analytical results on the level of FTA use in Australia. While this suggests that the level of FTA use would fall once FTA preferential margin contracted alongside a fall in the effective tariff rate, the current situation (in which the Doha round of WTO talks have stalled) suggests that the advantages of FTA use will be maintained.

In terms of problems with FTA use, the company questionnaire survey conducted in Japan and South Korea highlighted a lack of awareness and knowledge about FTAs and FTA use by companies, as well as the problems highlighted by the above statistical analysis of costs associated with acquiring certificates of origin and a small preferential margin for FTAs. When trying to raise rates of FTA use, it is important to disperse information and support the acquisition of certificates of origin by small and medium-sized companies.

\subsubsection{Analysis of the Impact of FTAs on Trade using Gravity Model}

Concerning the impact of FTAs on trade, there is the trade creation effect, whereby trade between FTA signatory countries expands, and the trade diversion effect, whereby imports to the signatory country shift from an efficient non-signatory country to an inefficient signatory country. While the trade creation effect improves economic welfare, the trade diversion effect is recognized as having the potential to reduce economic welfare. However, the impact of FTA on trade for the overall economies of the signatory countries is a combination of trade creation effect and trade diversion effect. Not only is it impossible to judge in advance whether or not the trade diversion effect will be positive or negative, it is also impossible to judge the size relationship between the trade creation effect and the trade diversion effect. The only method available is to carry out empirical analyses of the impact of FTAs on trade and make a judgment based upon the results.

Based on this recognition, Urata and Okabe (2010) examined the existence of a trade creation effect and trade diversion effect in a variety of FTAs throughout the world using a statistical analysis. For the analysis they used a gravity model, which is often used to determine trade volumes between countries. A gravity model applies the law of gravitation, whereby 
the gravitational attraction force between two point masses is directly proportional to the product of their masses and inversely proportional to the square of their separation distance, to international trade. In other words, the gravity model is one in which trade between two countries relies on the geographical distance between the countries and the size of their economies. In theory, the volume of trade between two countries establishes a relationship whereby the closer the geographical distance between the two countries and the larger the sizes of their economies (often economic size as shown by GDP), the greater the trade.

Urata and Okabe (2010) constructed a trade database for 67 countries across 20 products for the 27-year period from 1980 to 2006 using United Nations trade statistics. They used information on FTAs acquired from the WTO RTA database to analyze the existence of a trade creation effect and trade diversion effect in FTAs. In addition to using the geographical distance between two countries and their respective GDP as the basis for estimations in gravity models, the analysis also used border conditions between the two countries, the existence of a common language as an indicator of qualitative distance between the countries, and entry into FTAs as variables for explanation the amount of trade between two countries.

The estimation results are shown in Table 6 . Regarding the results, if the trade amount in FTA signatory countries is larger than the trade amount in countries that have not entered into FTAs, then the estimated coefficient on "trade creation" becomes positive and a trade creation effect is deemed to exist. At the same time, if the trade between FTA signatory countries and non-signatory countries is smaller than other combinations (such as trade between FTA signatory countries, and trade between non-signatory countries), then the estimated coefficient on "trade diversion" turns out to be negative and this is interpreted as the existence of a trade diversion effect.

If we use the above interpretation to look at the estimation results shown in Table 6, a trade creation effect can be deemed to exist in FTAs between developed countries in 18 of the 20 products, and no trade diversion effect can be seen whatsoever. However, in FTAs between developing countries, while a trade creation effect can be seen in 12 of the 20 products, a trade diversion effect was deemed to exist for 15 products. In theory, a higher possibility of a trade diversion effect occurring has been suggested in the event of a higher MFN tariff prior to the formulation of an FTA. Thus, the identification of a trade diversion effect for numerous products in FTAs between developing countries, which have higher tariffs than developed countries, is consistent with the theory.

The differences in trade creation effect and trade diversion effect comparing FTAs between developed countries and FTAs between developing countries can also be seen in the estimation results for NAFTA and AFTA. ${ }^{17)}$ If we classify NAFTA as an FTA between developed countries, and AFTA as an FTA between developing countries, the estimation results for the EU can be interpreted as falling between those for NAFTA and AFTA. While the EU started out as six developed countries, membership by medium-developed nations through the later participation of countries from Southern, Central and Eastern Europe is behind the observed results. The estimation results on the trade diversion effect show a need

17) However, in the case of NAFTA, the constituent members are the United States, Canada and Mexico, and while Mexico is an OECD member it is classified as a medium-developed nation rather than a developed nation in terms of its development. 


\section{S. Urata}

Table 6 Trade Creation and Trade Diversion Effects of FTAs

\begin{tabular}{|c|c|c|c|c|c|c|c|c|c|c|c|}
\hline & & \multicolumn{2}{|c|}{$\begin{array}{c}\text { FTAs } \\
\text { between } \\
\text { Developed } \\
\text { countries }\end{array}$} & \multicolumn{2}{|c|}{$\begin{array}{c}\text { FTAs } \\
\text { between } \\
\text { Developing } \\
\text { countries }\end{array}$} & \multicolumn{2}{|c|}{ EU } & \multicolumn{2}{|c|}{ NAFTA } & \multicolumn{2}{|c|}{ AFTA } \\
\hline & & $\mathrm{TC}$ & $\mathrm{TD}$ & $\mathrm{TC}$ & $\mathrm{TD}$ & $\mathrm{TC}$ & TD & $\mathrm{TC}$ & $\mathrm{TD}$ & $\mathrm{TC}$ & TD \\
\hline SITC01 & Meat and meat preparations & 0.59 & 0.13 & -0.40 & -0.77 & 1.82 & & 1.41 & -0.73 & & \\
\hline SITC04 & Cereals and cereal preparations & 0.79 & 0.17 & & & 0.30 & -0.39 & & 0.42 & 0.90 & \\
\hline SITC05 & Vegetables and fruit & 0.50 & 0.25 & -0.15 & -0.48 & 0.25 & & 1.41 & -0.12 & -0.48 & \\
\hline SITC24 & Cork and wood & & & -0.46 & -0.31 & & & & & & \\
\hline SITC26 & Textile fibers and their wastes & 0.40 & 0.27 & 0.78 & 0.86 & -0.25 & -0.42 & 1.13 & & 1.17 & 0.57 \\
\hline SITC33 & Petroleum, petroleum products & 0.69 & 0.50 & -0.26 & & & -0.34 & & 0.56 & 0.40 & \\
\hline SITC51 & Organic chemicals & & 0.22 & 0.51 & 0.45 & -0.40 & -0.18 & & 0.32 & 0.94 & -0.22 \\
\hline SITC52 & Inorganic chemicals & 0.10 & 0.21 & 0.22 & -0.19 & -0.27 & -0.17 & & 0.20 & 0.62 & -0.41 \\
\hline SITC54 & $\begin{array}{l}\text { Medicinal and Pharmaceutical } \\
\text { products }\end{array}$ & 0.37 & 0.16 & 0.72 & -0.31 & & & 0.31 & 0.18 & & -0.44 \\
\hline SITC63 & Cork and wood manufactures & 0.50 & 0.30 & & -0.19 & -0.15 & 0.18 & 1.09 & 0.46 & -1.65 & 0.29 \\
\hline SITC65 & $\begin{array}{l}\text { Textile yarn, fabrics, made-up } \\
\text { articles }\end{array}$ & 0.65 & 0.36 & 0.26 & -0.22 & & 0.21 & 1.01 & 0.27 & 0.23 & \\
\hline SITC67 & Iron and steel & 0.78 & 0.23 & 0.24 & -0.23 & -0.24 & & 0.56 & 0.48 & & -0.12 \\
\hline SITC68 & Non-ferrous metals & 0.69 & 0.27 & 0.26 & -0.16 & -0.16 & -0.12 & & 0.24 & -0.78 & \\
\hline SITC74 & General industrial machinery & 0.38 & 0.26 & 0.18 & -0.19 & -0.26 & 0.43 & 1.06 & 0.18 & 0.78 & -0.29 \\
\hline SITC75 & $\begin{array}{l}\text { Office machines and automatic } \\
\text { data processing equipment }\end{array}$ & 0.38 & 0.17 & 0.56 & 0.19 & -0.50 & -0.34 & & 0.19 & 1.83 & -0.19 \\
\hline SITC76 & $\begin{array}{l}\text { Telecommunications, sound } \\
\text { recording \& reproducing } \\
\text { equipment }\end{array}$ & 0.65 & 0.08 & 0.12 & -0.15 & 0.80 & 0.35 & 1.83 & -0.14 & 0.76 & \\
\hline SITC77 & Electric machinery & 0.56 & 0.47 & 0.31 & -0.31 & -0.12 & 0.28 & 1.02 & 0.37 & 0.47 & 0.10 \\
\hline SITC78 & Road vehicles & 1.21 & 0.23 & & -0.19 & 0.93 & 0.40 & 2.42 & & 1.31 & -0.39 \\
\hline SITC84 & Articles of apparels & 0.93 & 0.21 & & -0.24 & -0.45 & 0.37 & 0.67 & -0.14 & -0.83 & -0.54 \\
\hline SITC87 & $\begin{array}{l}\text { Professional and scientific } \\
\text { instruments }\end{array}$ & 0.40 & 0.12 & 0.28 & -0.10 & & 0.37 & 1.71 & 0.32 & 1.11 & -0.38 \\
\hline Signs & Positive & 18 & 19 & 12 & 3 & 5 & 8 & 13 & 13 & 12 & 3 \\
\hline Signs & Negative & 0 & 0 & 4 & 15 & 10 & 7 & 0 & 4 & 4 & 9 \\
\hline
\end{tabular}

Notes: TC and TD mean trade creation and trade diversion, respectively. Only the resutls with statistical significance are shown in the table.

Source: Urata and Okabe (2010)

to reduce the global most favored nation (MFN) tariff rate in order to avoid a trade diversion effect.

Estimated results by industry suggest that there is a larger trade creation effect in transportation machinery. These estimation results reflect the fact that high tariffs are imposed for 
transportation machinery, particularly automobiles. Trade will be encouraged if high tariffs can be reduced or abolished through FTAs.

\section{Conclusions}

In this article, I have introduced the results of an analysis on the economic effects of FTAs carried out by the Research Institute of Economy, Trade \& Industry (RIETI), led by the author. The analysis covered around ten FTAs, with a focus on the Asia Pacific region, but there is a need to carry out a similar analysis of more FTAs in order to deepen understanding of the effects of FTAs. The effects of FTAs were analyzed from the perspectives of both the quality and quantity of the FTAs. In the qualitative analysis, trade in goods, trade in services, direct investment and safeguard measures were analyzed from the perspective of the level of liberalization based on FTA rules. The analysis showed that in relation to rules on trade in goods, trade in services and direct investment, there is generally a higher level of liberalization in developed countries that in developing countries. Given the fact that the content of FTAs is becoming more comprehensive, it is important to expand the fields covered for analysis to areas such as the trade and investment facilitation, intellectual property rights, competition policy, and environmental policy.

The analysis of the quantitative effects of FTAs showed a trade expansion effect for many FTAs. However, expenses such as the acquisition of the necessary certificates of origin needed to use FTAs and cases such as a lower MFN tariff rate than the FTA tariff rate are obstacles to the use of FTAs. If these obstacles can be removed the trade expansion effect is likely to increase.

There are many issues of great interest concerning FTAs that were not covered by the analysis. For example, it would be extremely interesting to carry out an analysis of the factors that determine whether an FTA is formed from a political science framework in addition to an economics framework. The results of such analysis would no doubt be of great use to policymakers in formulating FTA policy. When carrying out an analysis of the effects of FTAs it is important to construct a theoretical model and carry out an empirical analysis in the form of an examination of the suggested hypothesis. Lastly, given that the form of trade liberalization that brings greatest benefit to the world as a whole is multilateral trade liberalization, there is a need to carry out an analysis from the perspectives of both theory and evidence of the impact of FTAs on multilateral trade liberalization negotiations.

\section{References}

Abe, Kazutomo (2010), “Assessing the Economic Impacts of Free Trade Agreements: A Computable Equilibrium Model Approach," in: Christopher Findlay and Shujiro Urata (eds.), Free Trade Agreements in the Asia Pacific. World Scientific Publishing, pp.165-194.

Ando, Mitsuyo (2009), "Impacts of FTAs in East Asia: CGE Simulation Analysis," RIETI Discussion Paper Series 09-E-037.

Cheong, Inkyo and Jungran Cho (2010), "Rules of Origin and Agricultural Trade Liberalization in Major Free Trade Agreements," in: Christopher Findlay and Shujiro Urata (eds.), Free Trade Agreements in the Asia Pacific. World Scientific Publishing, pp.1-28.

Cheong, Inkyo, Hansung Kim and Jungran Cho (2010), "Business Use of FTAs in Korea," RIETI Discussion Paper Series 10-E-038. 


\section{S. Urata}

Golub, S.S. (2003), "Measurement of restrictions on inward foreign direct investment for OECD countries," Economics Department Working Papers No. 357, OECD.

Kohpaiboon, Archanun (2010), "Exporters' Response to FTA Tariff Preferences: Evidence from Thailand," RIETI Discussion Paper Series 10-E-039.

Ministry of Economy, Trade and Industry (2010), Fukosei Boeki Hokokusho: WTO Kyotei oyobi Keizairenkei kyotei - Toshi Kyotei karamita Shuyokoku no Boueki Seisaku [Unfair Trading Report: Trade Policies of Major Countries from the Perspectives of WTO Agreements, Economic Partnership Agreements and Investment Agreements] Trade Policy Bureau [in Japanese].

Ochiai, Ryo, Phillipa Dee and Christopher Findlay (2010), "Services in Free Trade Agreements," in: Christopher Findlay and Shujiro Urata (eds.), Free Trade Agreements in the Asia Pacific. World Scientific Publishing, pp.29-80.

Pomfret, Richard, Uwe Kaufmann and Christopher Findlay (2010), “Use of FTAs in Australia,” RIETI Discussion Paper Series 10-E-042.

Takahashi, Katsuhide and Shujiro Urata (2010), "On the Use of FTAs by Japanese Firms: Further Evidence," Business and Politics 12 (1) Article 2.

Urata, Shujiro and Misa Okabe (2010), "Trade Creation and Diversion Effects of Regional Trade Agreements on Commodity Trade," RIETI Discussion Paper Series 10-E-007.

Urata, Shujiro and John Sasuya (2010), "Analysis of the Restrictions on Foreign Direct Investment in Free Trade Agreements," in: Christopher Findlay and Shujiro Urata (eds.), Free Trade Agreements in the Asia Pacific. World Scientific Publishing, pp.81-130.

Zhang, Yunling and Minghui Shen (2011), "The Status of East Asian Free Trade Agreements," ADBI Working Paper Series No. 282, Asian Development Bank Institute. 